\title{
ADDITIVE EFFECTS OF IODINE AND THIOUREA IN THE TREATMENT OF HYPERTHYROIDISM ${ }^{1}$
}

\author{
By T. S. DANOWSKI, E. B. MAN, AND A. W. WINKLER \\ (From the Departments of Internal Medicine and Psychiatry of Yale University School of \\ Medicine, and the Medical Service of the Nerw Haven Hospital and \\ Dispensary, New Haven)
}

(Received for publication February 20, 1946)

Evidence has already been presented that prior administration of iodine to patients with hyperthyroidism does not prevent the action of thiourea (1). Some cases behaved as if the action of iodine actually supplemented that of thiourea, but the evidence for such an additive effect was inconclusive. On the other hand, various writers have maintained that preliminary treatment with iodine delays the action of thiouracil (and so, possibly, of thiourea), even if it does not entirely obviate it (2 to 11). From a practical as well as a theoretical viewpoint it is essential to decide which interpretation is correct. If the actions of the two agents are additive, or at least do not interfere with one another, they may well be given together. If, on the other hand, the prior or simultaneous administration of iodine delays the action of thiourea, it would be advisable to avoid combined treatment.' The present study seeks to resolve this problem by a comparison of the effects in hyperthyroid patients of treatment with thiourea alone, and with both iodine and thiourea. Further observations on the treatment of hyperthyroidism with thiourea are included, particularly concerning the eventual need for thyroid medication to control hypothyroidism.

\section{MATERIALS AND METHODS}

Fifty-four patients in all were studied. Some data in 16 of these have been previously reported. The diagnosis of hyperthyroidism was based primarily upon the presence of a concentration of precipitable iodine in serum of 8 or more gamma per cent (12). Basal metabolic rate initially exceeded +20 per cent in all but 5 cases. In all cases the history, symptoms and physical findings were compatible with the diagnosis of hyperthyroidism. About 85 per cent of the patients in this series had diffuse enlargement of the thyroid gland, the remainder had toxic

\footnotetext{
1 This investigation was aided by a grant from the Fluid Research Funds of the Yale University School of Medicine.
}

adenomata. Unequivocal exophthalmos was present in one-third of the cases. No attempt was made to assign a particular plan of treatment to patients in any one of these categories. Four regimes were employed in the first few weeks of treatment. Sixteen patients received thiourea alone, either in a single daily dose of $0.28 \mathrm{gram}$, or in three daily doses of 0.07 gram. Fifteen patients were treated simultaneously with thiourea in similar dosage and with 5 drops of strong solution of iodine (U.S.P.) three times a day. Twenty-three patients were first treated with strong solution of iodine (15 drops daily) for periods ranging from 2 to 52 weeks, and then given thiourea. All but 5 of these patients were incompletely controlled on iodine medication alone, judging from the level of the serum iodine and the clinical status. In 17 of these the iodine was continued along with the thiourea medication, while in the remaining 6 iodine was discontinued as soon as the thiourea medication was begun. With remission of the hyperthyroidism and decline of the serum precipitable iodine to normal or subnormal levels, the dosage of thiourea was either decreased from 0.28 to 0.07 gram or less once daily, or else the patient was given desiccated thyroid, 0.03 to 0.06 gram daily. Administration of thiourea has been continued to date in all but 2 cases. In all patients determinations of the serum precipitable iodine $(13,14)$, the basal metabolic rate, the body weight, and the pulse rate were repeated at intervals of 2 to 10 weeks. Leukocyte and other blood counts were obtained, as well as urinalyses.

\section{RESULTS}

(A) Initial response to treatment. Administration of thiourea alone produced clinical improvement and a drop of the elevated concentration of precipitable iodine in serum to normal within 6 weeks in 11 out of 16 hyperthyroid patients (Figure 1A). Subsequently the serum iodine declined to normal levels in 2 of the 5 patients who failed to respond during the initial 6 weeks of treatment (M. W., C. V.). In 3 other patients (J. C., M. Ma., D. G.) the serum precipitable iodine rose again to hyperthyroid levels following the initial drop with a subsequent return to normal in 2 out of the 3 .

A comparison of Figures $1 \mathrm{~A}$ and $1 \mathrm{C}$ proves 


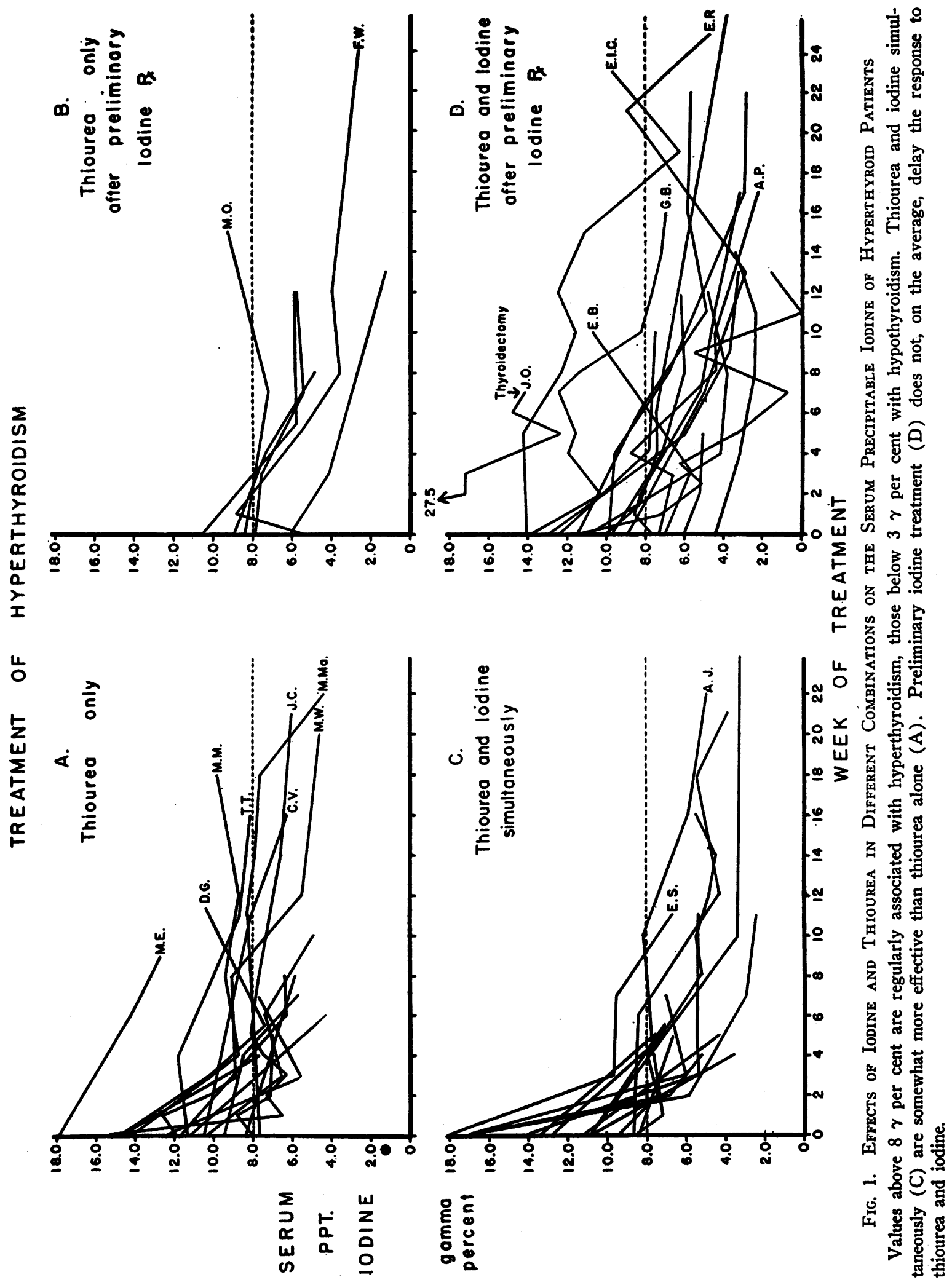


that iodine administered simultaneously with thiourea in no way delays the effectiveness of the latter. Actually, at the end of 6 weeks of treatment all but 2 of 15 patients had responded with a decrease in serum precipitable iodine to euthyroid concentrations. This result is to be contrasted with that observed in the group treated with thiourea alone, in which at the end of 6 weeks the serum iodine level had not returned to normal in 5 out of 16 patients. Furthermore, from the 6 th to the 16th week of treatment, the serum precipitable iodine declined inore consistently, and to a greater extent, with combined medication than with thiourea alone.

A comparison of Figure 1A with Figure 1D proves that the serum precipitable iodine did not, in general, fall any faster when thiourea alone was given to otherwise untreated cases (Figure 1A) than when it was given to those previously receiving iodine medication, providing iodine medication was not discontinued (Figure 1D). In only 3 cases (G. B., E. I. C., J. O.) in the group which received a preliminary and concurrent course of iodine the serum iodine remained above normal 6 weeks after thiourea was started, a result as satisfactory as that obtained with thiourea alone. The first patient has since responded; the second has continued to be partially refractory for many months, and the third had a thyroidectomy performed after 7 weeks of treatment. In this patient the serum precipitable iodine decreased from 27.5 to 14.2 gamma per cent before operation. Temporary exacerbations under treatment were observed in 3 other patients (A. P., E. B., E. R.).

Comparison of Figures $1 \mathrm{~A}$ and $1 \mathrm{~B}$ is somewhat unsatisfactory because of the paucity of cases in the latter group. In one case of Figure 1B ( $F$. W.) there was a transient relapse following the substitution of thiourea for iodine medication. In another patient (M. O.) thiourea alone produced only a temporary remission. The other 4 declined during the first 6 weeks as fast as did the patients in Figure 1A.

(B) Later response to treatment. Normal or subnormal levels of serum precipitable iodine appeared after 4 months with equal frequency in all 4 treatment regimes. Thus the eventual effects of thiourea alone, in the dosage employed, could not be distinguished from those of iodine plus thiourea.
The concentration of precipitable iodine in serum was allowed to decrease to hypothyroid levels in 18 of the 54 patients before the therapeutic regime was altered, while in the others it was permitted to decline only to euthyroid levels. Changes in regime were made one at a time, usually at intervals of several weeks.

(1) Effect of reduction in dosage of thiourea (Table I). It was possible gradually to decrease the daily dosage of thiourea with only infrequent exacerbations as a result. In 19 patients the initial daily dose of thiourea $(0.28 \mathrm{gram}$ at one time, or 0.21 gram divided into 3 equal portions) was reduced to a single daily maintenance dose of 0.07 gram after 2 to 54 weeks of treatment. In 2 of these patients (E. A. C. and C. S.), the dose was further reduced to 0.04 gram daily. Re-

TABLE I

Effect of reduction in dosage of thiourea, after initial remission of hyperthyroidism, on the serum precipitable iodine and the basal metabolic rate

\begin{tabular}{|c|c|c|c|c|c|c|}
\hline \multirow[b]{2}{*}{ Patient } & \multicolumn{3}{|c|}{ Daily treatment } & \multirow{2}{*}{$\begin{array}{l}\text { Duration } \\
\text { from start } \\
\text { of thiourea }\end{array}$} & \multirow{2}{*}{$\begin{array}{l}\text { Serum } \\
\text { precipi- } \\
\text { tablet } \\
\text { iodine } \\
\text { iod* }\end{array}$} & \multirow{2}{*}{$\begin{array}{c}\text { Basal } \\
\text { meta- } \\
\text { bolic } \\
\text { rate** }\end{array}$} \\
\hline & $\begin{array}{l}\text { Thio- } \\
\text { urea }\end{array}$ & $\begin{array}{c}\text { Strong } \\
\text { solu- } \\
\text { tion of } \\
\text { iodine }\end{array}$ & $\begin{array}{l}\text { Desic- } \\
\text { cated } \\
\text { thyroid }\end{array}$ & & & \\
\hline & grams & drops & grams & weeks & $\begin{array}{l}\text { gamma } \\
\text { per cent }\end{array}$ & per cent \\
\hline E.B. & $\begin{array}{l}0.28 \\
0.07\end{array}$ & $\begin{array}{l}15 \\
15\end{array}$ & $\begin{array}{l}0.06 \\
0.03\end{array}$ & $\begin{array}{r}0 \text { to } 48 \\
48 \text { to } 54\end{array}$ & $\begin{array}{l}4.9 \\
4.9\end{array}$ & $\begin{array}{l}+10 \\
-3\end{array}$ \\
\hline W.B. & $\begin{array}{l}0.28 \\
0.08\end{array}$ & $\begin{array}{l}5 \\
5\end{array}$ & & $\begin{array}{c}0 \text { to } 9 \\
9 \text { to } 50 \\
50 \text { to } 65\end{array}$ & $\begin{array}{l}3.4 \\
5.4 \\
6.8\end{array}$ & \\
\hline E.A.C. & $\begin{array}{l}0.21 * \\
0.07 \\
0.04\end{array}$ & $\begin{array}{l}15 \\
15 \\
15\end{array}$ & & $\begin{array}{r}0 \text { to } 15 \\
15 \text { to } 25 \\
25 \text { to } 31\end{array}$ & $\begin{array}{l}4.2 \\
4.4 \\
3.5\end{array}$ & $\begin{array}{l}+4 \\
-13 \\
-20\end{array}$ \\
\hline A.B. & $0.21^{*}$ & $\begin{array}{r}15 \\
5 \\
5\end{array}$ & & $\begin{array}{l}0 \text { to } 2 \\
2 \text { to } 4 \\
4 \text { to } 12\end{array}$ & $\begin{array}{r}4.3 \\
10.8\end{array}$ & \\
\hline J.C. & $\begin{array}{l}0.21^{*} \\
0.07\end{array}$ & & & $\begin{array}{r}0 \text { to } 30 \\
30 \text { to } 41\end{array}$ & $\begin{array}{l}4.8 \\
5.0\end{array}$ & $\begin{array}{l}+3 \\
-6\end{array}$ \\
\hline M.G. & $\begin{array}{l}0.21^{*} \\
0.07\end{array}$ & & & $\begin{array}{r}0 \text { to } 11 \\
11 \text { to } 19\end{array}$ & $\begin{array}{l}4.8 \\
6.5\end{array}$ & $\begin{array}{l}+9 \\
+3\end{array}$ \\
\hline B.G. & $\begin{array}{l}0.28 \\
0.07\end{array}$ & & $\begin{array}{l}0.06 \\
0.03\end{array}$ & $\begin{array}{r}2 \text { to } 54 \\
54 \text { to } 62\end{array}$ & $\begin{array}{l}3.1 \\
5.7\end{array}$ & \\
\hline P.G. & $\begin{array}{l}0.28 \\
0.28 \\
0.07\end{array}$ & $\begin{array}{l}15 \\
15 \\
15\end{array}$ & $\begin{array}{l}0.03 \\
0.03\end{array}$ & $\begin{array}{r}0 \text { to } 17 \\
17 \text { to } 32 \\
32 \text { to } 40\end{array}$ & $\begin{array}{l}3.0 \\
2.9 \\
3.9\end{array}$ & $\begin{array}{l}-25 \\
-23 \\
-25\end{array}$ \\
\hline S.L. & $\begin{array}{l}0.28 \\
0.07\end{array}$ & 5 & $\begin{array}{l}0.03 \\
0.03\end{array}$ & $\begin{array}{l}34 \text { to } 51 \\
51 \text { to } 56\end{array}$ & $\begin{array}{l}1.7 \\
4.6\end{array}$ & $\begin{array}{l}-4 \\
-8\end{array}$ \\
\hline M.M. & $\begin{array}{l}0.28 \\
0.07\end{array}$ & & & $\begin{array}{r}0 \text { to } 50 \\
50 \text { to } 62\end{array}$ & $\begin{array}{l}5.3 \\
4.7\end{array}$ & $\begin{array}{l}+15 \\
+6\end{array}$ \\
\hline
\end{tabular}


TABLE I-Continued

\begin{tabular}{|c|c|c|c|c|c|c|}
\hline \multirow[b]{2}{*}{ Patient } & \multicolumn{3}{|c|}{ Daily treatment } & \multirow{2}{*}{$\begin{array}{l}\text { Duration } \\
\text { from start } \\
\text { of thiourea }\end{array}$} & \multirow{2}{*}{$\begin{array}{l}\text { Serum } \\
\text { precipi- } \\
\text { table† } \\
\text { iodine** }\end{array}$} & \multirow{2}{*}{$\begin{array}{l}\text { Basal } \\
\text { meta- } \\
\text { bolic } \\
\text { rate* }\end{array}$} \\
\hline & $\begin{array}{l}\text { Thio- } \\
\text { urea }\end{array}$ & $\begin{array}{l}\text { Strong } \\
\text { solu- } \\
\text { tion of } \\
\text { iodine }\end{array}$ & $\begin{array}{c}\text { Desic- } \\
\text { cated } \\
\text { thyroid }\end{array}$ & & & \\
\hline M:S. & $\begin{array}{l}\text { grams } \\
0.28 \\
0.07 \\
0.28 \\
0.07\end{array}$ & drops & $\begin{array}{l}\text { grams } \\
\\
0.06 \\
0.06 \\
0.03\end{array}$ & $\begin{array}{c}\text { weeks } \\
7 \text { to } 26 \\
26 \text { to } 41 \\
41 \text { to } 46 \\
46 \text { to } 63\end{array}$ & \begin{tabular}{|c|} 
gamma \\
per cent \\
6.5 \\
9.3 \\
7.4 \\
4.6
\end{tabular} & $\begin{array}{c}\text { per cent } \\
+19 \\
+37 \\
+27\end{array}$ \\
\hline C.S. & $\begin{array}{l}0.21^{*} \\
0.07 \\
0.04\end{array}$ & $\begin{array}{l}15 \\
15 \\
15\end{array}$ & & $\begin{array}{r}0 \text { to } 8 \\
8 \text { to } 11 \\
11 \text { to } 14\end{array}$ & $\begin{array}{l}2.4 \\
2.4 \\
3.6\end{array}$ & $\begin{array}{l}-19 \\
-26 \\
-24\end{array}$ \\
\hline F.W. & $\begin{array}{l}0.21 * \\
0.07\end{array}$ & & & $\begin{array}{r}0 \text { to } 24 \\
24 \text { to } 34\end{array}$ & $\begin{array}{l}2.7 \\
4.9\end{array}$ & \\
\hline M.W. & $\begin{array}{l}0.28 \\
0.07\end{array}$ & & & $\begin{array}{r}0 \text { to } 26 \\
26 \text { to } 32\end{array}$ & $\begin{array}{l}4.6 \\
4.6\end{array}$ & $\begin{array}{l}-15 \\
-18\end{array}$ \\
\hline M.P. & $\begin{array}{l}0.28 \\
0.07\end{array}$ & & $\begin{array}{l}0.06 \\
0.06\end{array}$ & $\begin{array}{r}0 \text { to } 52 \\
52 \text { to } 59\end{array}$ & $\begin{array}{l}4.1 \\
3.9\end{array}$ & $\begin{array}{l}+10 \\
+8\end{array}$ \\
\hline J.H. & $\begin{array}{l}0.28 \\
0.07\end{array}$ & $\begin{array}{l}15 \\
15\end{array}$ & $\begin{array}{l}0.06 \\
0.03\end{array}$ & $\begin{array}{r}0 \text { to } 71 \\
71 \text { to } 81\end{array}$ & $\begin{array}{l}3.9 \\
4.5\end{array}$ & $\begin{array}{l}-1 \\
-7\end{array}$ \\
\hline M.K. & $\begin{array}{l}0.28 \\
0.07\end{array}$ & & $\begin{array}{l}0.06 \\
0.03\end{array}$ & $\begin{array}{r}0 \text { to } 50 \\
50 \text { to } 60\end{array}$ & $\begin{array}{l}2.9 \\
5.9\end{array}$ & $\begin{array}{l}-3 \\
+16\end{array}$ \\
\hline F.M. & $\begin{array}{l}0.21^{*} \\
0.21^{*} \\
0.07\end{array}$ & $\begin{array}{l}5 \\
5\end{array}$ & 0.03 & $\begin{array}{r}0 \text { to } 13 \\
13 \text { to } 20 \\
20 \text { to } 30\end{array}$ & $\begin{array}{l}2.4 \\
5.1 \\
5.5\end{array}$ & $\begin{array}{l}-23 \\
+23 \\
+19\end{array}$ \\
\hline M.A. & $\begin{array}{l}0.21^{*} \\
0.07\end{array}$ & $\begin{array}{l}15 \\
15\end{array}$ & & $\begin{array}{l}0 \text { to } 4 \\
4 \text { to } 12\end{array}$ & $\begin{array}{l}7.1 \\
6.3\end{array}$ & $\begin{array}{l}-13 \\
-8\end{array}$ \\
\hline
\end{tabular}

* Divided into three equal doses.

** At the end of the period.

† Serum precipitable iodine always exceeded 8.0 gamma per cent at the start of thiourea medication (zero day). The iodine concentration in patient B.G. at 2 weeks was 6.1, in patient S.L. at 34 weeks 5.0, and in patient M.S. 5.1 gamma per cent at 7 weeks.

duction of dosage was followed by an exacerbation of hyperthyroidism in one patient (M. S.) who had previously been controlled for 26 weeks with 0.28 gram of thiourea daily. Resumption of this dosage again induced a remission. The hyperthyroidism has remained in abeyance with the smaller dosage of thiourea in the other 18 patients. They have now been followed for periods of time ranging from 4 to 41 weeks.

Thiourea has been discontinued in 2 patients (W. B. and A. B.), after 50 weeks and 2 weeks of thiourea treatment respectively. Patient W. B. has remained well to date, 15 weeks following the withdrawal of thiourea, although iodine therapy has been continued; the second patient (A. B.) suffered a relapse within 10 weeks.
(2) Effect of omission of the strong solution of iodine (Figure 2). Iodine solution was omitted after varying intervals of treatment (1 to 31 weeks) in 6 patients in whom thyroid overactivity was completely controlled by simultaneous administration of thiourea and strong solution of iodine. In 4 of the 6 patients serum precipitable iodine and basal metabolic rate promptly rose to hyperthyroid levels. There was also a recurrence of the symptoms of hyperthyroidism. These changes were present at 5 to 8 weeks following withdrawal of the iodine solution, and, judging from the patient's histories, may well have developed earlier. Two of the 4 patients (B. P. and W. B.) were again given iodine as well as thiourea with prompt disappearance of all signs and symp-

TABLE II

Effect of treatment with desiccated thyroid on the serum precipitable iodine of patients, previously hyperthyroid, who had become euthyroid or hypothyroid under treatment with thiourea

\begin{tabular}{|c|c|c|c|c|c|c|}
\hline \multirow[b]{2}{*}{ Patient } & \multicolumn{3}{|c|}{ Daily treatment } & \multirow{2}{*}{$\begin{array}{l}\text { Duration } \\
\text { from start } \\
\text { of thiourea }\end{array}$} & \multirow{2}{*}{$\begin{array}{l}\text { Serum } \\
\text { precipi- } \\
\text { table } \\
\text { iodine* }\end{array}$} & \multirow{2}{*}{$\begin{array}{l}\text { Basal } \\
\text { meta- } \\
\text { bolic } \\
\text { rate* }\end{array}$} \\
\hline & $\begin{array}{l}\text { Thio- } \\
\text { urea }\end{array}$ & $\begin{array}{c}\text { Strong } \\
\text { solu- } \\
\text { tion of } \\
\text { iodine }\end{array}$ & $\begin{array}{c}\text { Desic- } \\
\text { cated } \\
\text { thyroid }\end{array}$ & & & \\
\hline E.B. & $\begin{array}{c}\text { grams } \\
0.28 \\
0.28\end{array}$ & $\begin{array}{c}d r o p s \\
15 \\
15\end{array}$ & $\begin{array}{l}\text { grams } \\
0.06\end{array}$ & $\begin{array}{c}\text { weeks } \\
0 \text { to } 12 \\
12 \text { to } 48\end{array}$ & \begin{tabular}{|c|} 
gammer cent \\
4.8 \\
4.9
\end{tabular} & $\begin{array}{c}\text { per cent } \\
-9 \\
+10\end{array}$ \\
\hline B.G. & $\begin{array}{l}0.28 \\
0.28 \\
0.28\end{array}$ & & $\begin{array}{l}0.06 \\
0.06\end{array}$ & $\begin{array}{r}0 \text { to } 19 \\
19 \text { to } 32 \\
32 \text { to } 54\end{array}$ & $\begin{array}{l}1.3 \\
4.0 \\
3.1\end{array}$ & \\
\hline P.G. & $\begin{array}{l}0.20 \\
0.20\end{array}$ & 15 & 0.03 & $\begin{array}{r}0 \text { to } 17 \\
17 \text { to } 32\end{array}$ & $\begin{array}{l}3.0 \\
2.9\end{array}$ & $\begin{array}{l}-25 \\
-23\end{array}$ \\
\hline J.H. & $\begin{array}{l}0.20 \\
0.20\end{array}$ & $\begin{array}{l}15 \\
15\end{array}$ & 0.06 & $\begin{array}{l}25 \text { to } 29 \\
29 \text { to } 67\end{array}$ & $\begin{array}{l}0.5 \\
4.2\end{array}$ & $\begin{array}{l}+10 \\
-1\end{array}$ \\
\hline M.K. & $\begin{array}{l}0.20 \\
0.20\end{array}$ & & 0.06 & $\begin{array}{r}1 \text { to } 12 \\
12 \text { to } 50\end{array}$ & $\begin{array}{l}5.8 \\
2.9\end{array}$ & $\begin{array}{l}+11 \\
-3\end{array}$ \\
\hline S.L. & $\begin{array}{l}0.20 \\
0.20 \\
0.20\end{array}$ & $\begin{array}{l}15 \\
15 \\
15\end{array}$ & $\begin{array}{l}0.06 \\
0.03\end{array}$ & $\begin{array}{r}0 \text { to } 23 \\
23 \text { to } 28 \\
28 \text { to } 51\end{array}$ & $\begin{array}{l}2.9 \\
6.3 \\
1.7\end{array}$ & $\begin{array}{l}-19 \\
+36 \\
-4\end{array}$ \\
\hline B.P. & $\begin{array}{l}0.07 \\
0.07\end{array}$ & $\begin{array}{l}10 \\
10\end{array}$ & 0.06 & $\begin{array}{r}0 \text { to } 13 \\
13 \text { to } 26\end{array}$ & $\begin{array}{l}3.2 \\
7.0\end{array}$ & $\begin{array}{l}-14 \\
+1\end{array}$ \\
\hline A.P. & $\begin{array}{l}0.14 \\
0.14\end{array}$ & $\begin{array}{l}5 \\
5\end{array}$ & 0.03 & $\begin{array}{r}0 \text { to } 17 \\
17 \text { to } 39\end{array}$ & $\begin{array}{l}2.2 \\
4.3\end{array}$ & $\begin{array}{l}-6 \\
-15\end{array}$ \\
\hline M.P. & $\begin{array}{l}0.28 \\
0.28\end{array}$ & & 0.06 & $\begin{array}{r}0 \text { to } 14 \\
14 \text { to } 52\end{array}$ & $\begin{array}{l}2.9 \\
4.1\end{array}$ & $\begin{array}{l}+10 \\
+10\end{array}$ \\
\hline M.S. & $\begin{array}{l}0.28 \\
0.28\end{array}$ & & 0.06 & $\begin{array}{r}0 \text { to } 20 \\
20 \text { to } 32\end{array}$ & $\begin{array}{l}0.6 \\
6.4\end{array}$ & +17 \\
\hline
\end{tabular}

* At the end of the period. 
toms of hyperthyroidism. One of the other 2 patients (A. L.) was again controlled by increasing the dose of thiourea without the use of iodine solution.

Both patients in whom omission of the iodine solution was not followed by a recurrence of hyperthyroidism ultimately developed the low concentrations of serum precipitable iodine characteristic of hypothyroidism.

In 2 cases shown in Figure 2 (B. P. and A. P.) the iodine present in the desiccated thyroid which they were receiving did not prevent a recurrence of hyperthyroidism when the strong solution of iodine was discontinued.

(3) Effect of desiccated thyroid. Eight patients received 0.03 to 0.06 gram of desiccated thyroid, U.S.P., following the development of hypothyroid levels of serum precipitable iodine (3.2 to 0.6 gamma per cent) (Table II). In 2 other patients (E. B. and M. K.) thyroid therapy was started before the serum precipitable iodine had decreased to abnormally low concentration. The response to thyroid medication was most irregular. In some patients even the larger dose of dried thyroid, 0.06 gram daily, did not suffice to restore the serum precipitable iodine, or, in one patient (M. K.) to prevent a further decline. The smaller dose, 0.03 gram daily, proved inadequate in 2 of the 3 patients to whom it was given.

(C) Toxic reactions. Two patients developed drug fever up to $103^{\circ}$ necessitating withdrawal of the thiourea. The treatment period, 7 and 10 days respectively, was too brief to affect the hyperthyroidism, and these 2 patients are not included in this series.

There have been no skin eruptions. Urine analyses and complete blood counts have remained within normal limits in all patients.

In occasional patients malaise and nausea were present at the start of treatment. These symptoms usually disappeared either spontaneously, or fol-

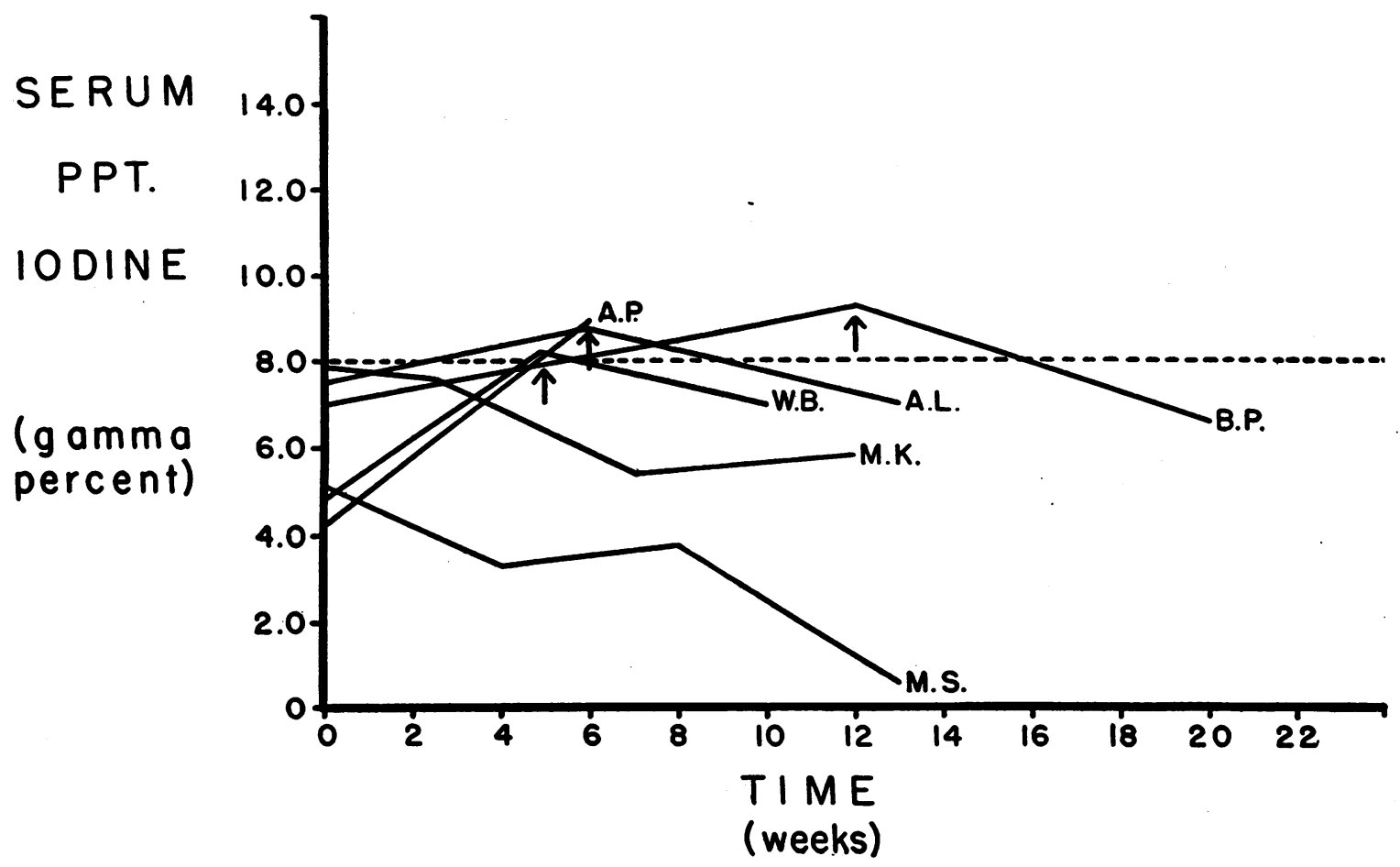

Fig. 2. Effect of Withdrawal of Iodine Solution in Patients in Remission on Iodine and Thiourea Withdrawal of iodine medication in patients in remission on combined iodine and thiourea therapy resulted in a rise in the serum precipitable iodine in 4 of 6 instances (A. P., W. B., A. L., and B. P.). Resumption of iodine medication at points indicated by arrows in patients W. B. and B. P. again produced a remission. A similar effect was produced by doubling the dosage of thiourea, at the point indicated by the arrow, in patient A. L. This is proof of continued additive effects of iodine and thiourea medication. 
lowing temporary reduction in the dosage of thiourea.

(D) Relation between changes in serum precipitable iodine and the basal metabolic rate. Changes in these two measurements tended to parallel one another, but the fall in serum iodine often preceded that of the basal metabolic rate. The converse was never true. Thus, in 34 cases in which there were sufficient data, the fall of the serum iodine from supranormal to normal levels preceded that of the metabolic rate in 15 instances while in 19 no lag was detected. The lag of the metabolic rate behind the serum iodine was even more evident when the latter fell to subnormal levels, since it was present in 5 of the 7 cases studied.

\section{DISCUSSION}

These experiments furnish strong evidence against any theory that the action of iodine in hyperthyroidism antagonizes that of thiourea. They do not support the common opinion that preliminary medication with iodine delays the action of the thio-drugs in the hyperthyroid patient, whatever may be their relationship in the normal rat (15). There is, on the other hand, considerable evidence that the actions of the two substances are additive. The relapse of the hyperthyroidism when iodine alone was discontinued in patients controlled with a combination of iodine and thiourea (Figure 2) is almost conclusive. These relapses are all the more significant since the trend of the serum precipitable iodine is generally downward as thiourea medication is continued over a long period of time. The quickest and most pronounced remissions occurred in patients who had received and continued to receive iodine. Indeed, from a comparison of Figures $1 B$ and $1 D$, it seems quite probable that the widespread belief that preliminary iodine medication delays the action of thiouracil and thiourea may be related to the practice of discontinuing the iodine at the time these drugs are started. This procedure might superimpose a relapse due to release from iodine effect upon the inhibition due to the thio-drug, with consequent delay in remission. The argument that excess thyroglobulin stored during the preliminary period of iodine administration might cause a delay in the response to thiourea because of the time required for its degradation, has never been entirely satisfactory. No hyperthyroidism follows the discontinuance of iodine therapy in euthyroid subjects, although extra iodoprotein is stored in the gland and is later destroyed (16). The rapid response of patients on iodine solution and thiourea cannot be ascribed to iodine alone, since almost all of the patients failed to develop a complete remission during the preliminary course of iodine. Furthermore, although iodine solution may in a small percentage of cases produce a return of serum precipitable iodine to normal limits, a depression of the serum precipitable iodine to hypothyroid levels with this agent alone would be almost unprecedented.

These observations not only should remove all fear of giving iodine prior to or along with thiourea, but provide a positive basis for recommending combined therapy. The recurrence of the hyperthyroidism with omission of iodine medication in patients on combined therapy (Figure 2) is positive proof that the administration of iodine may permit a smaller dose of thiourea to be effective. In view of the potential toxicity of all drugs of this series, the practical advantage from such reduction of dosage is obvious. Since there is no reason to believe that the mode of action of thiourea differs from that of thiouracil or its derivatives, this conclusion can logically be extended to medical treatment with all substances of this class. Combined therapy has, indeed, been introduced as a preoperative measure $(3,7)$, since hyperplasia and operative bleeding are much reduced. The common practice of using the drugs seriatim should be replaced by simultaneous administration throughout the preoperative period, as well as for prolonged medical therapy. Demonstration that iodine and thiourea medication are additive in their effects supports and supplements the work of Rawson and his associates (17), who have examined the thyroid gland histologically during a remission induced by thiouracil medication alone, and again after a course of combined iodine and thiouracil medication. They found that, although the functional hyperthyroidism remained in abeyance, the intense hyperplasia induced by the thiouracil treatment alone had partly resolved after the iodine had been given, even though thiouracil medication was continued. 
This points to different and independent inhibitory actions by each agent, which might be additive.

The progressive decline in thyroid activity as thiourea was continued meant that dosage was often cut drastically in order to avoid hypothyroidism (Table $\mathrm{I}$ ). It is not certain, however, that this can be ascribed simply to a greater specific efficacy of thiourea as the hyperthyroidism came under control. Quite possibly remissions might eventually have been produced with doses of 0.07 gram daily continued from the start as well as with initial doses of 0.28 gram which were subsequently reduced. There certainly is a time as well as a dosage factor involved in the action of the drug. The experience with thiouracil in normal subjects is interesting in this respect, since it required weeks or months to induce hypothyroidism, even with large doses $(18,19)$.

In some of the patients at least, the hyperthyroidism was merely in remission rather than cured, since reduction in thiourea dosage or withdrawal of iodine solution was followed by a rise in serum precipitable iodine (Table I and Figure 2).

This remission was apparently produced as readily in patients with toxic adenomata as it was in those with diffuse goiter. The promptness of response varied greatly from patient to patient. The time interval necessary to produce the remission seems to be unrelated to the initial level of serum precipitable iodine, or to the severity of the hyperthyroidism.

Hypothyroidism developing during the course of prolonged medical treatment of hyperthyroidism is a regrettable complication, both because of the general reaction of the patient, and because of the possibility that exophthalmos may be favored. The difficulty of its control is enhanced by the tendency toward progressive decline of thyroid activity in many patients while receiving the same dose of thiourea. Clinically the evidences of this type of hypothyroidism are mild but distinct, consisting mainly of feelings of chilliness, drawling speech, psychomotor retardation, and sometimes excessive weight gain. The fall in basal metabolic rate often lags behind that of the serum iodine, and behind the earlier clinical symptoms, and so is not always a reliable guide. The hypothyroidism can be controlled either by administration of desiccated thyroid or by reduction in dosage of thiourea, but both these procedures entail the danger of recurrence of the hyperthyroidism. Further studies of the optimal regime for control of the hypothyroidism are now in progress.

\section{CONCLUSIONS}

1. Thiourea and iodine medication supplement rather than interfere with one another in the treatment of hyperthyroidism. This is established (a) by the more marked remission during the first 3 or 4 months produced by the two substances in combination than that produced by thiourea alone; and $(b)$ by the recurrence of hyperthyroidism in some patients maintained in remission by both substances when iodine alone is discontinued.

2. Preliminary iodine medication does not delay the action of thiourea, provided iodine therapy is not discontinued.

3. Thyroid activity tends to decline slowly and progressively over many months during the course of prolonged medication with thiourea. If hypothyroidism is to be avoided, this necessitates reduction of dosage of thiourea to one-fourth or even one-eighth of the amount given initially.

4. Hypothyroidism may also be corrected by oral administration of dried thyroid. The necessary dosage varies considerably from subject to subject, and lies between 0.03 and more than 0.06 gram daily.

5. Preoperative or prolonged medical therapy with thiourea and kindred drugs should in general be supplemented at all times with iodine.

\section{BIBLIOGRAPHY}

1. Danowski, T. S., Man, E. B., and Winkler, A. W., Treatment of hyperthyroidism with a combination of iodine, thiourea in small doses, and desiccated thyroid. Am. J. M. Sc., 1945, 202, 777.

2. Barr, D. P., and Shorr, E., Observations on the treatment of Graves' disease with thiouracil. Ann. Int. Med., 1945, 23, 754.

3. Bartels, E. L., Use of thiouracil in the preoperative preparation of patients with severe hyperthyroidism. Ann. Int. Med., 1945, 22, 365.

4. Beardwood, J. T., and Levinson, D. C., Thiouracil in the medical management of hyperthyroidism. Pennsylvania Medical Journal, 1944, 48, 212.

5. Eaton, J. C., Treatment of thyrotoxicosis with thiouracil. Lancet, 1945, 1, 171.

6. Gabrilove, J. L., Kert, M. J., and Soffer, L. J., The use of thiouracil in the treatment of patients with hyperthyroidism. Ann. Int. Med., 1945, 23, 537.

7. Lahey, F. H., Bartels, E. C., Warren, S., and Meissner, W. A., Thiouracil-its use in the preoperative 
treatment of severe hyperthyroidism. Surg., Gynec. and Obst., 1945, 81, 425.

8. Palmer, M. V., Hyperthyroidism and thiouracil. Ann. Int. Med., 1945, 22, 335.

9. Reveno, W. S., Thyrotoxicosis treated with thiouracil. J. A. M. A., 1944, 126, 153.

10. Watson, E. M., Thiouracil in the control of thyrotoxicosis. J. Clin. Endocrinol., 1945, 5, 273.

11. Williams, R. H., and Clute, H. M., Thiouracil in the treatment of thyrotoxicosis. New England J. Med., 1944, 230, 657.

12. Winkler, A. W., Riggs, D. S., Thompson, K. W., and Man, E. B., Serum iodine in hyperthyroidism, with particular reference to the effects of subtotal thyroidectomy. J. Clin Invest., 1946, 25, 404.

13. Man, E. B., Smirnow, A. W., Gildea, E. F., and Peters, J. P., Serum iodine fractions in hyperthyroidism. J. Clin. Invest., 1942, 21, 773.
14. Riggs, D. S., and Man, E. B., A permanganate acid ashing micromethod for iodine determinations. I. Values in blood of normal subjects. J. Biol. Chem., 1940, 134, 193.

15. Astwood, E. B., Chemotherapy of hyperthyroidism. The Harvey Lectures, 1944-1945.

16. Salter, W. T., The Endocrine Function of Iodine. Harvard University Press, 1940.

17. Rawson, R. W., Moore, F. D., Peacock, W., Means, J. H., Cope, O., and Riddell, C. B., Effect of iodine on the thyroid gland in Graves' disease when given in conjunction with thiouracil, a two-action theory of iodine. J. Clin Invest., 1945, 24, 869.

18. Raab, W., Thiouracil treatment of angina pectoris. J. A. M. A., 1945, 128, 249.

19. Riggs, D. S., The effect of thiouracil medication on the serum precipitable iodine of euthyroid subjects. To be published. 